\title{
WATER DEPTH AND THICKNESS OF SEDIMENT IN RESERVOIRS 1 AND 2, FRAMINGHAM AND ASHLAND, MASSACHUSETTS
}

By John A. Izbicki and Gene W. Parker

U.S. GEOLOGICAL SURVEY

Open-File Report 91-508

Prepared in cooperation with the

U.S. ENVIRONMENTAL PROTECTION AGENCY

WASTE MANAGEMENT DIVISION, REGION I

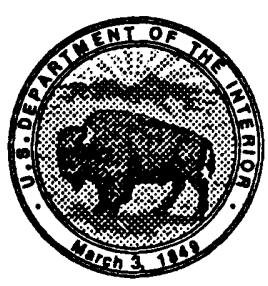

Marlborough, Massachusetts 1991 


\section{U.S. DEPARTMENT OF THE INTERIOR}

\section{MANUEL LUJAN, JR., Secretary}

U.S. GEOLOGICAL SURVEY

Dallas L. Peck, Director

For additional information write to:

\section{District Chief}

Water Resources Division

U.S. Geological Survey

28 Lord Road, Suite 280

Marlborough, MA 01752
Copies of this report can be purchased from:

U.S. Geological Survey

Books and Open-File Reports Section

Federal Center, Bldg. 810

Box 25425,

Denver, CO 80225 


\section{CONTENTS}

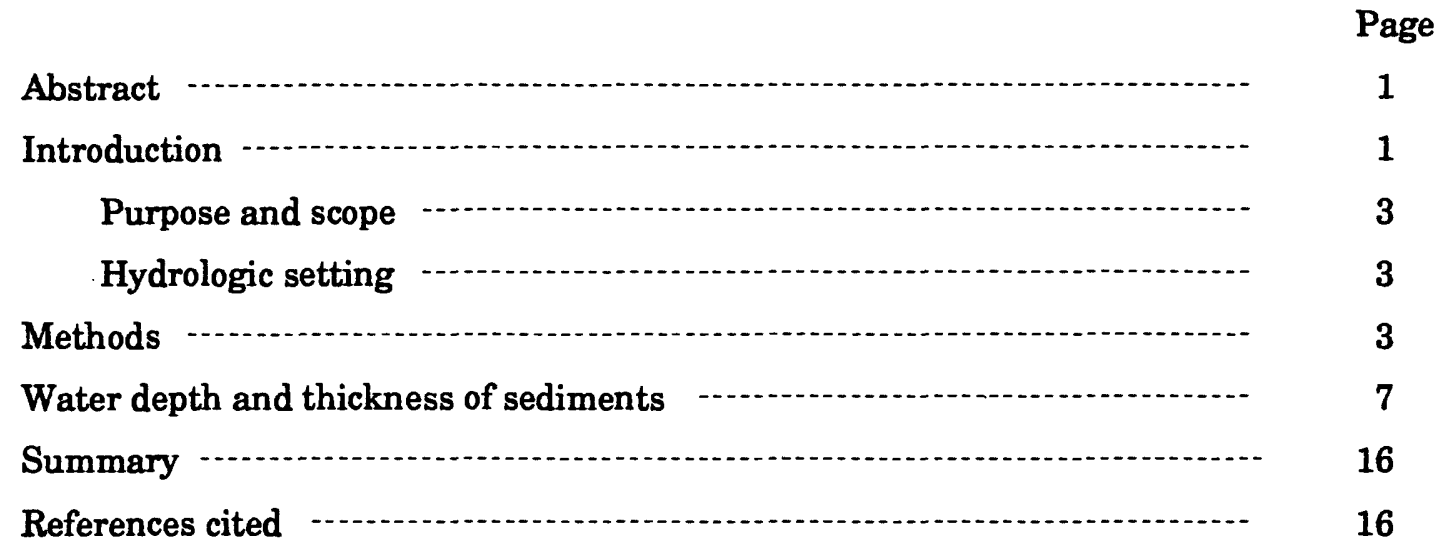

\section{ILLUSTRATIONS}

Figure 1. Map showing location of study area

2. Diagram showing ground-penetrating radar system

3. Map showing location of radar profile lines in Reservoir 1, Framingham,

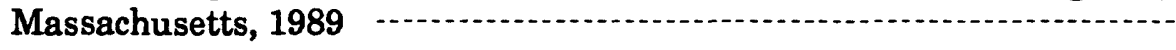

4. Map showing location of radar profile lines in Reservoir 2, Framingham and Ashland, Massachusetts, 1989

5. Plots of field radar record, interpreted profile line, and penetration measurements for profile line $A-A^{\prime}$ in Reservoir 1, Framingham, Massachusetts, 1989

6. Plots of field radar record, interpreted profile line, and penetration measurements for profile line B-B' in Reservoir 2, Framingham and Ashland, Massachusetts, 1989

7. Plot of comparisons of water depths determined from ground-penetrating radar and field measurements in Reservoirs 1 and 2, Framingham and

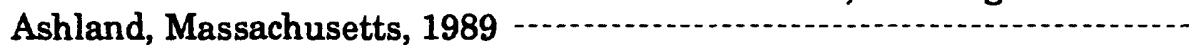

8. Plot of comparisons of soft-sediment thickness using ground-penetrating radar and field measurements in Reservoirs 1 and 2, Framingham and

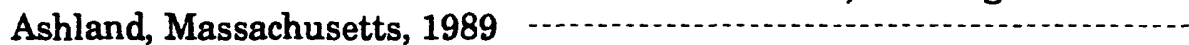

9. Map showing water depth in Reservoir 1, Framingham, Massachusetts, 1989

10. Map showing water depth in Reservoir 2, Framingham and Ashland,

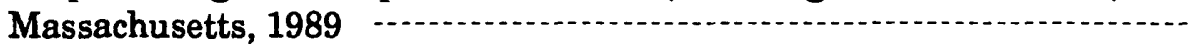

11. Map showing sediment distribution in Reservoir 1, Framingham,

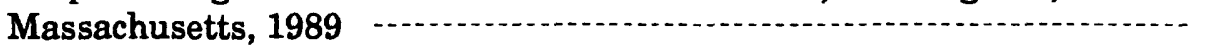

12. Map showing sediment distribution in Reservoir 2, Framingham and Ashland, Massachusetts, 1989 


\section{TABLES}

Table 1. Electromagnetic properties and velocity of radar waves in selected earth

\section{CONVERSION FACTORS}

\begin{tabular}{lcl}
\hline Multiply & By & To obtain \\
\hline & Length & \\
& 25.4 & millimeter \\
inch (in.) & 0.3048 & meter \\
foot (ft) & 1.609 & kilometer \\
mile (mi) & Area & \\
& 2.59 & square kilometer \\
square mile (mi ${ }^{2}$ ) & Yelocity & \\
& 0.3048 & meter per \\
& & nanosecond \\
foot per nanosecond (ft/ns) & Flow & \\
& 0.2832 & cubic meter per \\
& & second
\end{tabular}




\title{
WATER DEPTH AND THICKNESS OF SEDIMENT IN RESERVOIRS 1 AND 2, FRAMINGHAM AND ASHLAND, MASSACHUSETTS
}

\author{
By John A. Izbicki and Gene W. Parker
}

\begin{abstract}
Ground-penetrating radar was used to determine water depth and thickness of sediments in Reservoirs 1 and 2 on the Sudbury River in Framingham and Ashland, Massachusetts. More than 7 miles of ground-penetrating radar profiles were obtained during August 28 to September 1, 1989. Maximun water depth was 13 feet in Reservoir 1 and 18.5 feet in Reservoir 2. The greatest accumulations of sediment were in the northwestern arm of Reservoir 1 and in the southern part of Reservoir 2 near the Sudbury River inlet where sediment thickness was greater than 2 feet. Sediment accumulations were less than 1 foot near the upstream part of the southwestern arm of Reservoir 1 and the downstream part of Reservoir 2. In the remainder of Reservoirs 1 and 2, the sediment thickness was generally 1 to 2 feet. Depth of water and sediment thickness were checked by sounding and penetration measurements along selected profile lines.
\end{abstract}

\section{INTRODUCTION}

The Nyanza Superfund Site is an approximately 62-acre area formerly used for manufacturing and waste disposal in Ashland, Massachusetts. Heavy metals have migrated in ground water from the site to the Sudbury River located approximately $600 \mathrm{ft}$ north of the site (fig. 1) (Pam Shields, U.S. Environmental Protection Agency, written communication, May 16, 1991). The U.S. Environmental Protection Agency (USEPA) is currently conducting a remedial investigation to determine the extent of contamination in the Sudbury River. Mercury from the Nyanza Superfund Site has been found in sediment samples as far as 16 mi downstream in Concord. The USEPA investigation area extends from the Nyanza Site to the confluence with the Assabet River in Concord, Massachusetts. Investigations by the USEPA include sampling of sediment, surface water, and biota within the upstream part of the Sudbury River. Information on depth of water and distribution of sediment in Reservoir 1 and 2 was needed to guide selection of sample locations. 


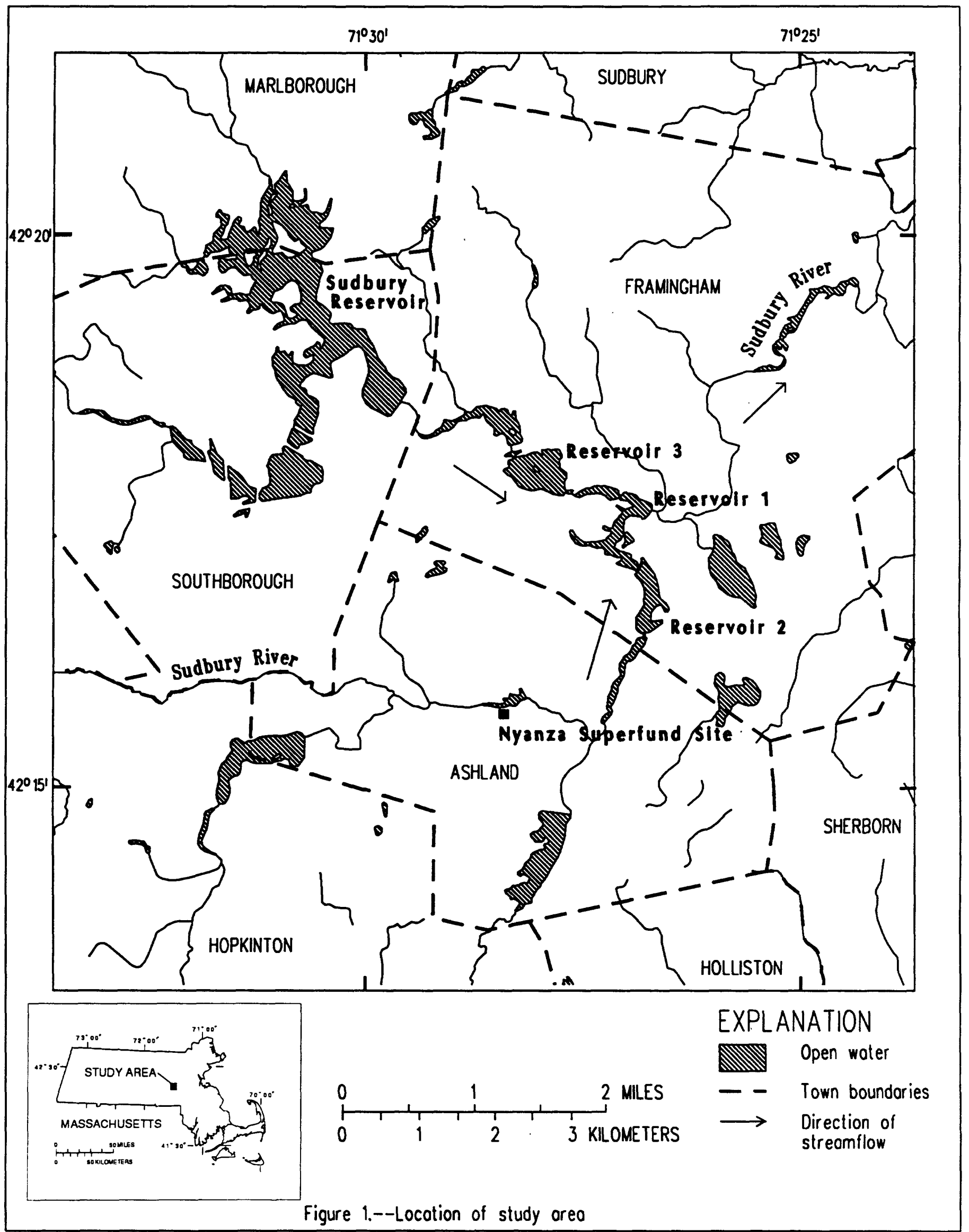




\section{Purpose and Scope}

The purpose of this report is to present the results of a reconnaissance study to map water depth and sediment thicknesses in Reservoirs 1 and 2, Framingham and Ashland, Massachusetts. The data obtained from this study will be used to guide selection of bottommaterial sampling locations in Reservoirs 1 and 2 as part of USEPA's remediation activities at the Nyanza Superfund Site.

This study included collection and interpretation of ground-penetrating radar (GPR) data for Reservoirs 1 and 2 and verification of selected radar profiles by field measurements of water depth and sediment thickness. The field measurements were made by U. S. Geological Survey personnel from the Massachusetts-Rhode Island District during August 28 to September 1, 1989. Additional water-depth and sediment-thickness data would be necessary if quantitative estimates of reservoir capacity or total sediment volume are desired.

\section{Hydrologic Setting}

Reservoirs 1 and 2 were built as water supplies in 1878, and have a surface area of 0.19 and $0.18 \mathrm{mi}^{2}$, respectively. The total drainage area for these two reservoirs is $75.2 \mathrm{mi}^{2}$. The Sudbury River flows eastward from Ashland into Reservoir 2 and northeastward from Reservoir 2 into the southwestern arm of Reservoir 1 (fig. 1). A tributary, which includes Sudbury Reservoir and Reservoir 3, flows into the northwestern arm of Reservoir 1 . The Sudbury River flows out of the northeastern end of Reservoir 1.

The average annual discharge below Reservoir 1 is $118 \mathrm{ft}^{3} / \mathrm{s}$ (U.S. Geological Survey, 1989). Additional flow data are available from the U.S. Geological Survey gaging station at Saxonville, Massachusetts (station number 01098530) located about $4 \mathrm{mi}$ downstream of Reservoir 1. The reservoirs are bounded by unconsolidated glacial till and stratified-drift deposits (Brackley and Hansen, 1985). The Nyanza Superfund Site in Ashland, Massachusetts, is located about 1 mi upstream from Reservoir 2 (fig. 1).

\section{METHODS}

Ground penetrating radar was selected for use in this study because it is a versatile system capable of either deep penetration of water and sediments when using a lowfrequency antenna or shallow penetration and detailed resolution when using a higher frequency antenna. Radar signals are not affected by aquatic vegetation, and GPR can be used in water depths as shallow as 0.5 feet (Izbicki and others, 1988). Previous studies have shown that radar can be used to determine the thickness of lake sediments (Haeni, and others, 1987) and stream sediments (Izbicki and others, 1988). 
Ground penetrating radar systems radiate short pulses of electromagnetic energy from a transmitting antenna. This energy enters the material (in this study, the water column and bottom sediments) and passes through the material until it encounters an interface between materials having different dielectric constants. At this interface, some of the energy is reflected. The greater the difference in dielectric constant between the two materials at the interface, the stronger the reflected energy. The reflected energy is detected by a surface receiver, and the travel time and strength of signal is recorded. Additional electronic equipment records and displays the reflected signal (fig. 2). Graphic records of the reflected energy portray a strong energy signal as a dark-gray or black return and a weaker energy signal as a light-gray return. A water-saturated organic interface would reflect a weaker energy signal than a water-clay interface. As travel time increases, a signal's strength decreases and a lighter gray return is recorded. Some signals may be lost completely during long transits.

The graphic radar record shows the travel time for a signal to pass through the water column and sediment, reflect off an interface, and return to the surface. This two-way travel time is measured in nanoseconds ( $1 \times 10^{-9}$ seconds). Travel time can be converted to thickness of material, if the dielectric constant of the material is known, using the following formula:

$$
\mathrm{d}=\mathrm{V}_{\mathrm{m}}(\mathrm{t} / 2)
$$

where: $V_{m}=c /\left(E_{r}\right)^{1 / 2}$

$d$ is the thickness of material, in feet;

$t$ is the two-way travel time, in nanoseconds;

$\mathrm{V}_{\mathrm{m}}$ is the radar wave velocity, in feet per nanosecond;

$c$ is the speed of light in free space, in feet per nanosecond $(0.9835712 \mathrm{ft} / \mathrm{ns})$; and

$\mathrm{E}_{\mathrm{r}}$ is the dielectric constant of the material (a dimensionless ratio).

The dielectric constants and velocities of radar waves, and approximate conductivities of selected materials are given in table 1.

Radar-signal penetration depends on the electrical conductivity of the materials encountered (Olhoeft, 1984) and the frequency of the radar signal (Izbicki and others, 1988). In general, radar signals will penetrate low-conductivity (resistive) earth materials to greater depths than conductive (low-resistivity) materials, depth of penetration increases with decreasing signal frequency, and resolution increases with increasing signal frequency. On the basis of curves developed by Olhoeft (1984), the penetration of a 300-megahertz (Mhz) radar wave in a column of freshwater is about $32 \mathrm{ft}$.

Another factor that affects the depth of penetration is the instrument range or maximum length of "listening" time between signal transmission and reception. A commercial GPR system with a 300-Mhz frequency antenna was used to profile the water depth and thickness of sediments in Reservoirs 1 and 2. This system had a maximum range of about 380 nanoseconds. For a radar wave velocity of of $0.11 \mathrm{ft} / \mathrm{ns}$ for freshwater (table 1 ), from equation 1, the maximum depth of water through which the GPR system could detect a reflecting surface is $20.9 \mathrm{ft}$. Therefore, the system range, rather than the penetration of the radar wave, was the factor limiting water-depth measurements. 


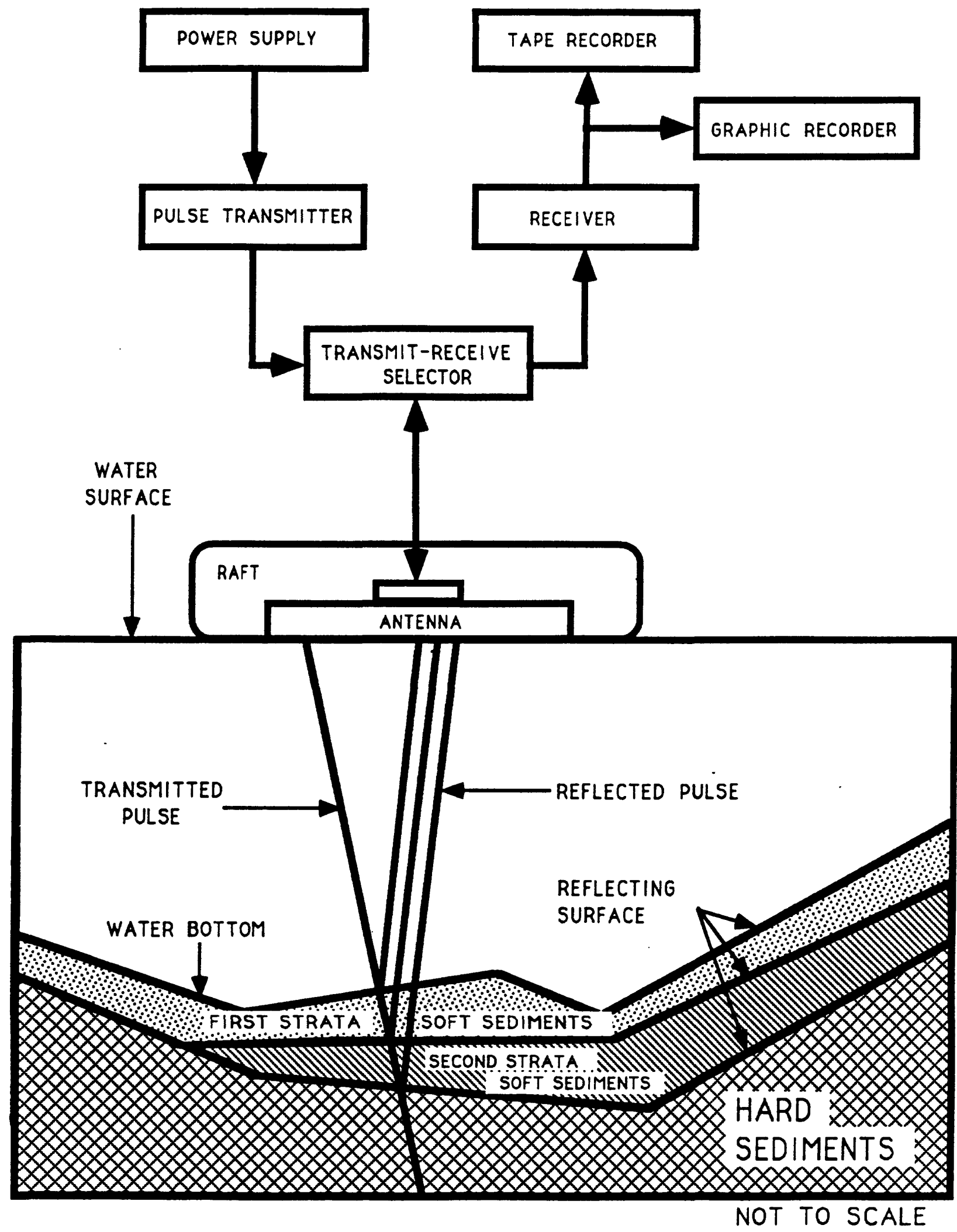

Figure 2.--Ground-penetrating radar system. 
Table 1.--Electromagnetic properties and velocity of radarwaves in selected earth materials, from Markt (1988)

[ft/ns, feet per nanosecond; mho/m, mho per meter]

\begin{tabular}{lrcc}
\hline Materials & $\begin{array}{l}\text { approximate } \\
\text { dielectric } \\
\text { constant }\end{array}$ & $\begin{array}{l}\text { Radarwave } \\
\text { velocity } \\
\text { (ft/ns) }\end{array}$ & $\begin{array}{c}\text { Approximate } \\
\text { conductivity } \\
\text { (mho/m) }\end{array}$ \\
\hline Air & 1 & 0.98 & 0 \\
Limestone & 7 & .37 & $10 \mathrm{E}-9$ \\
Granite (dry) & 5 & .44 & $10 \mathrm{E}-8$ \\
Sand (dry) & 4 to 6 & $\sim .44$ & $10 \mathrm{E}-7$ to $10 \mathrm{E}-3$ \\
Bedded salt & 3 to 6 & $\sim .46$ & $10 \mathrm{E}-5$ to $10 \mathrm{E}-4$ \\
Freshwater ice & 4 & .49 & $10 \mathrm{E}-5$ to $10 \mathrm{E}-3$ \\
Permafrost & 4 to 8 & $\sim .40$ & $10 \mathrm{E}-4$ to $10 \mathrm{E}-2$ \\
Sand, saturated & 30 to 50 & $\sim .16$ & $10 \mathrm{E}-4$ to $10 \mathrm{E}-2$ \\
Freshwater & 81 & .11 & $10 \mathrm{E}-4$ to 3 X $10 \mathrm{E}-2$ \\
Silt, saturated & 10 & .31 & $10 \mathrm{E}-3$ to $10 \mathrm{E}-2$ \\
Rich agricultural & 15 & .25 & $10 \mathrm{E}-2$ \\
Clay, saturated & 8 to 12 & $\sim .31$ & $10 \mathrm{E}-2$ to 1 \\
Sea water & 81 & .11 & 4 \\
\hline
\end{tabular}


The GPR equipment was mounted in an inflatable raft, and the antenna (also in an inflatable raft) was towed alongside. Approximately $7 \mathrm{mi}$ of radar profile lines were run. Location of profiles were determined using identifiable features on the lake shore and triangulation procedures (figs. 3 and 4). Although every effort was made to tow the antenna at a uniform speed, some variation in speed was unavoidable because of changing wind conditions and water currents. As a result, the interval and scale on the horizontal axis (distance) of the radar profiles are variable, but the control points allow for location of features on the profile.

The graphical field radar records were interpreted first by identifying soft sediments as a light-gray return and the underlining hard sediments as a dark-gray return (figs. 5 and 6). Then, from velocities and travel times calculated from dielectric constants reported in a previous study by Markt (1988) (table 1), the water depth and soft-sediment thickness were determined.

During data analysis, it was assumed that the radar wave velocity for soft sediments is similar to that of peat, and that the radar velocity is constant for soft sediments throughout the lake (Haeni and others, 1987). The exact nature of the sediments in Reservoirs 1 and 2 were not verified because of safety concerns associated with sampling and handling of sediments (Alan Klinger, U.S. Environmental Protection Agency, oral commun., September 1989). The radar velocities determined from eqs. 1 and 2 were $0.13 \mathrm{ft} / \mathrm{ns}$ for soft sediments.

Water-depth and sediment-penetration measurements were made on October 4, 1989 , along four selected radar profile lines for comparison to interpreted data. Two of these profile lines are shown in figures 5 and 6 . Water depths were determined by sounding with a calibrated 2-in. inside-diameter plastic pipe at selected intervals along a tag line stretched across a section of the resevoir close to a radar profile line. Sediment thickness was determined by driving the pipe into the bottom sediments at each location sounded. Measurements were obtained from two sounding lines on each reservoir as shown in figures 7 and 8. Water depths and sediment thicknesses from the soundings and penetration measurements were compared to GPR surveys for 43 locations. Most interpreted radarmeasured values were within $1 \mathrm{ft}$ of the measured water depth and sediment thickness. The outliers beyond the \pm 1 -ft agreement lines in figures 7 and 8 may result from not being able to relocate radar profile lines exactly. For reconnaissance purposes, a \pm 1 -ft error in sediment thickness is considered acceptable for determining the location of sediment deposits having thicknesses greater than $2 \mathrm{ft}$.

\section{WATER DEPTH AND THICKNESS OF SEDIMENTS}

The results of the water-depth surveys are summarized by hand-drawn contour lines in figures 9 and 10. Maximum water depth in Reservoir 1 was approximately $13 \mathrm{ft}$. Maximum water depth in Reservoir 2 was $18.5 \mathrm{ft}$ near the dam at the northern end of the reservoir. The streambed of the Sudbury River prior to impoundment is clearly visible by following the line of maximum depth from the inlet to Reservoir 2 along the Sudbury River and from the tributary inlet to the northwestern arm of Reservoir 1 to the outlet dam for Reservoir 1. 


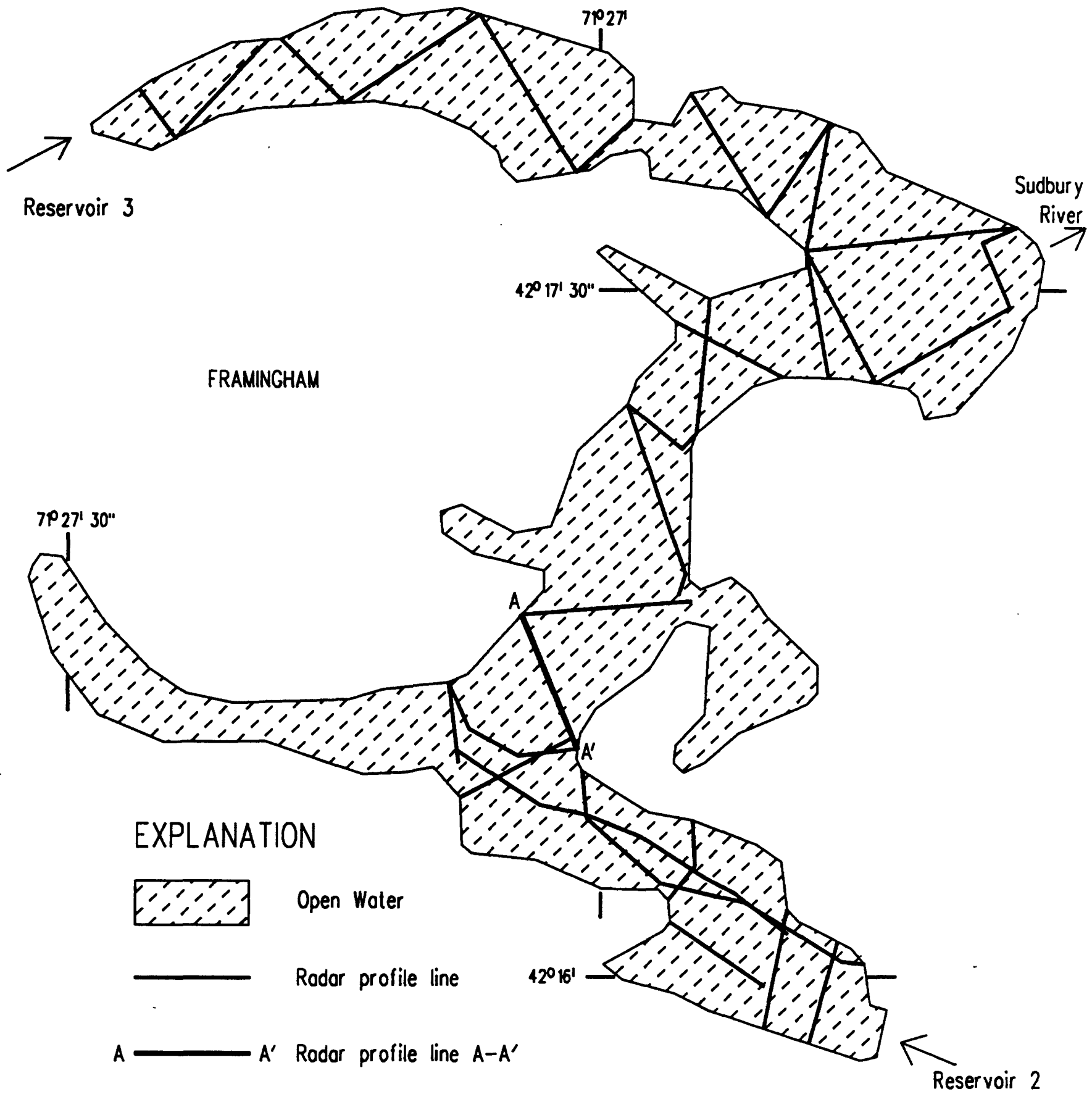

$\longrightarrow$ Direction of streamflow

Direction of streamflow

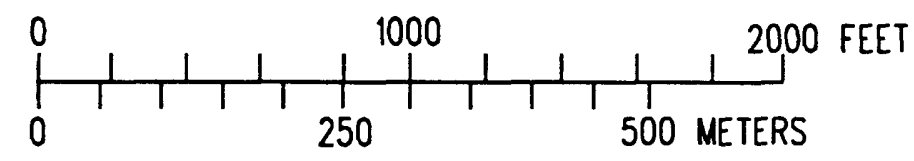

Figure 3.--Location of rodor profile lines in Reservoir 1, Frominghom, Massochusetts, 1989 


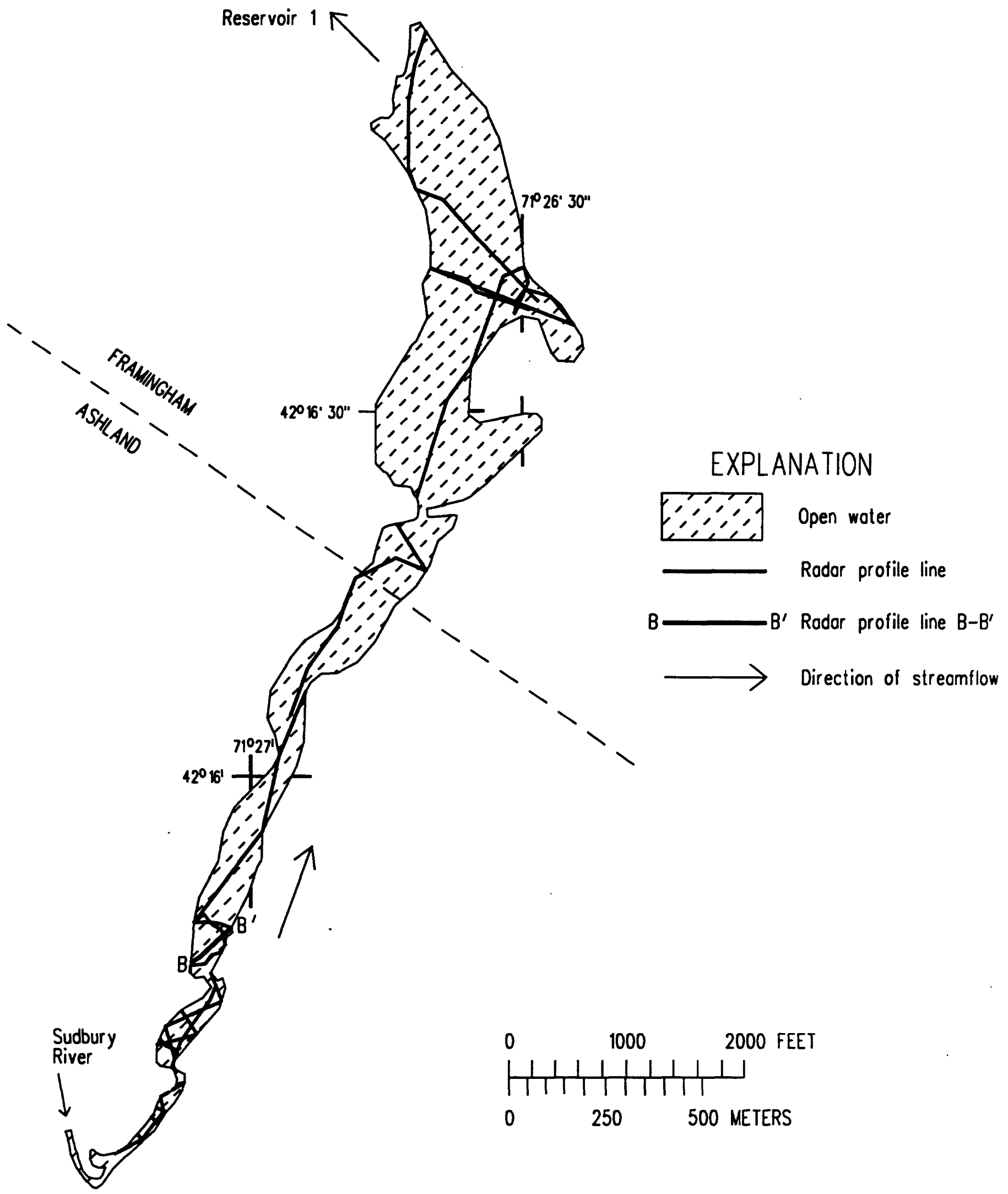

Figure 4.--Location of radar profile lines in Reservoir 2, Frominghom and Ashland, Massochusetts, 1989 


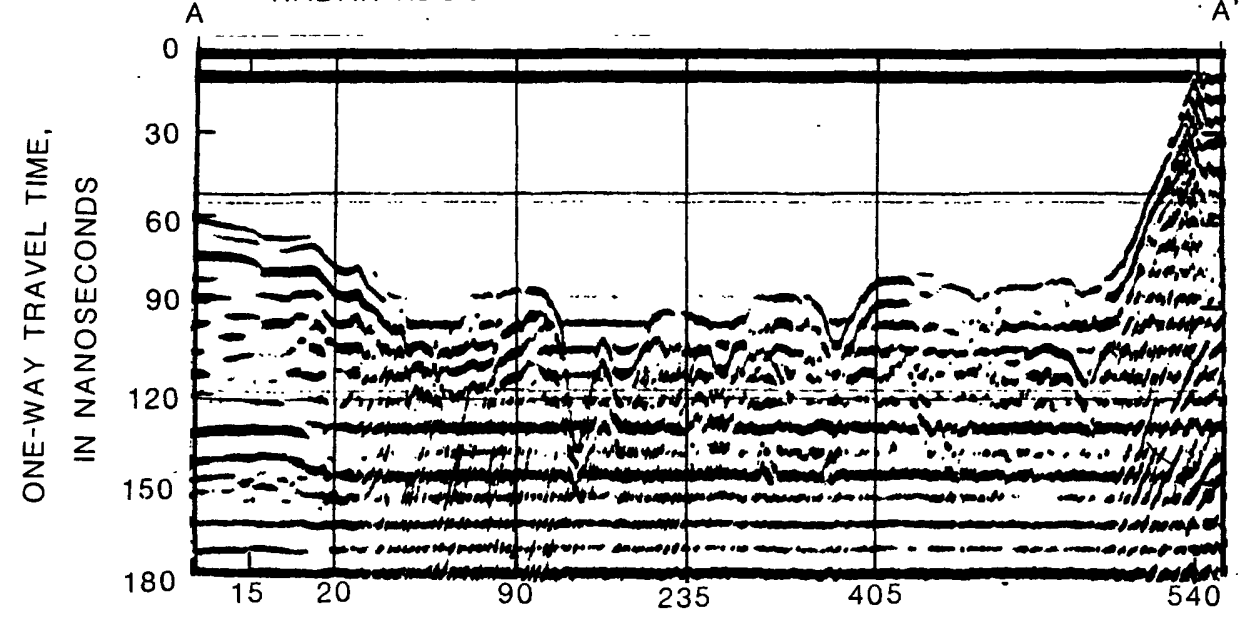

INTERPRETED PROFILE

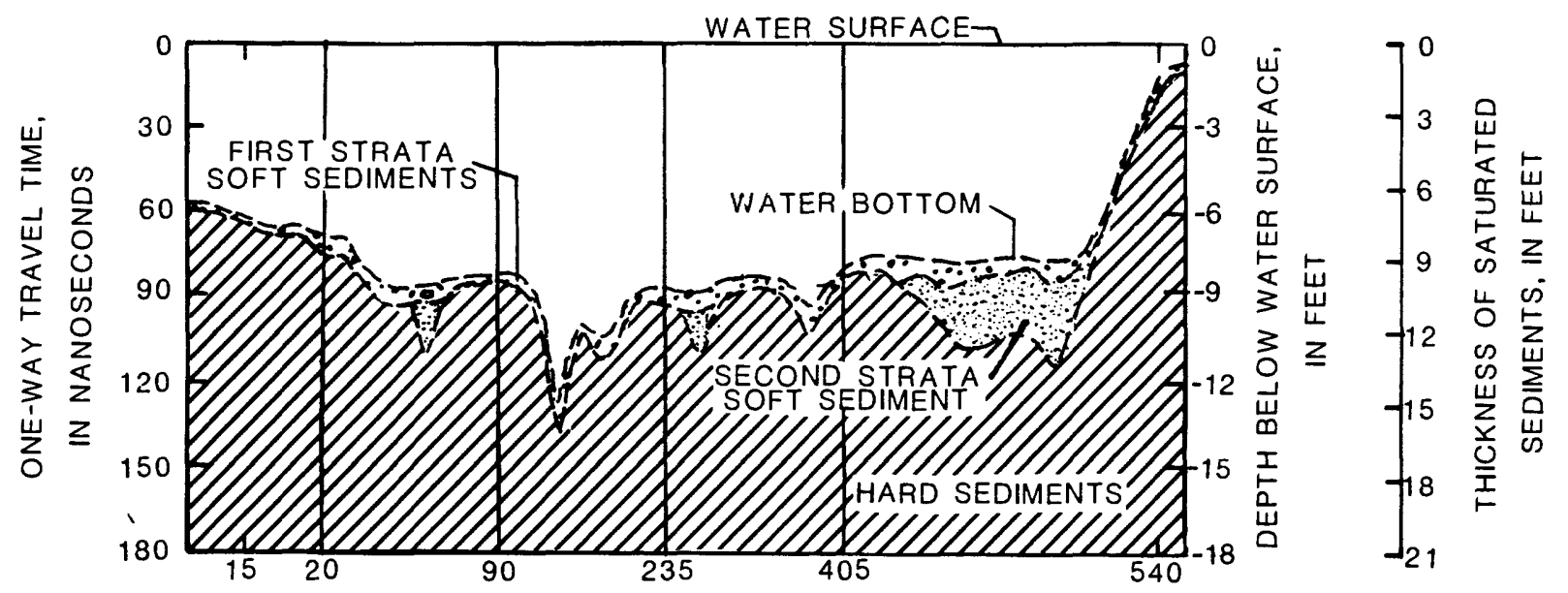

PENETRATION MEASUREMENT

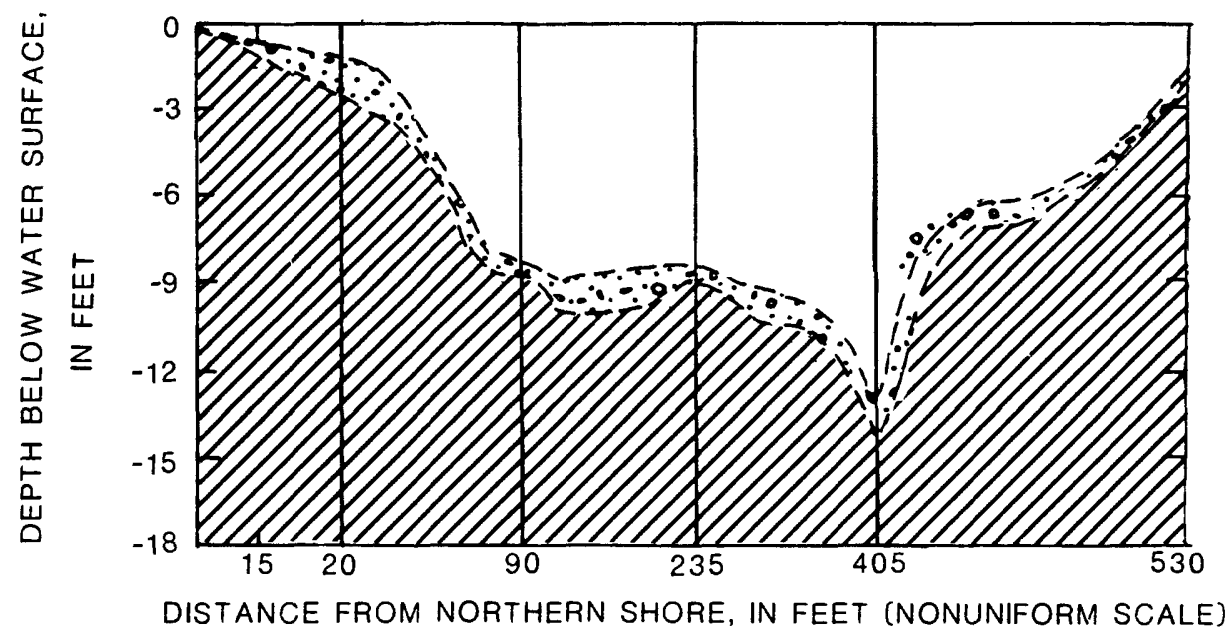

Figure 5.-Field radar record, interpreted profile line; and penetration measurements for profile line A-A' in Reservoir 1, Framingham, Massachusetts, 1989. 

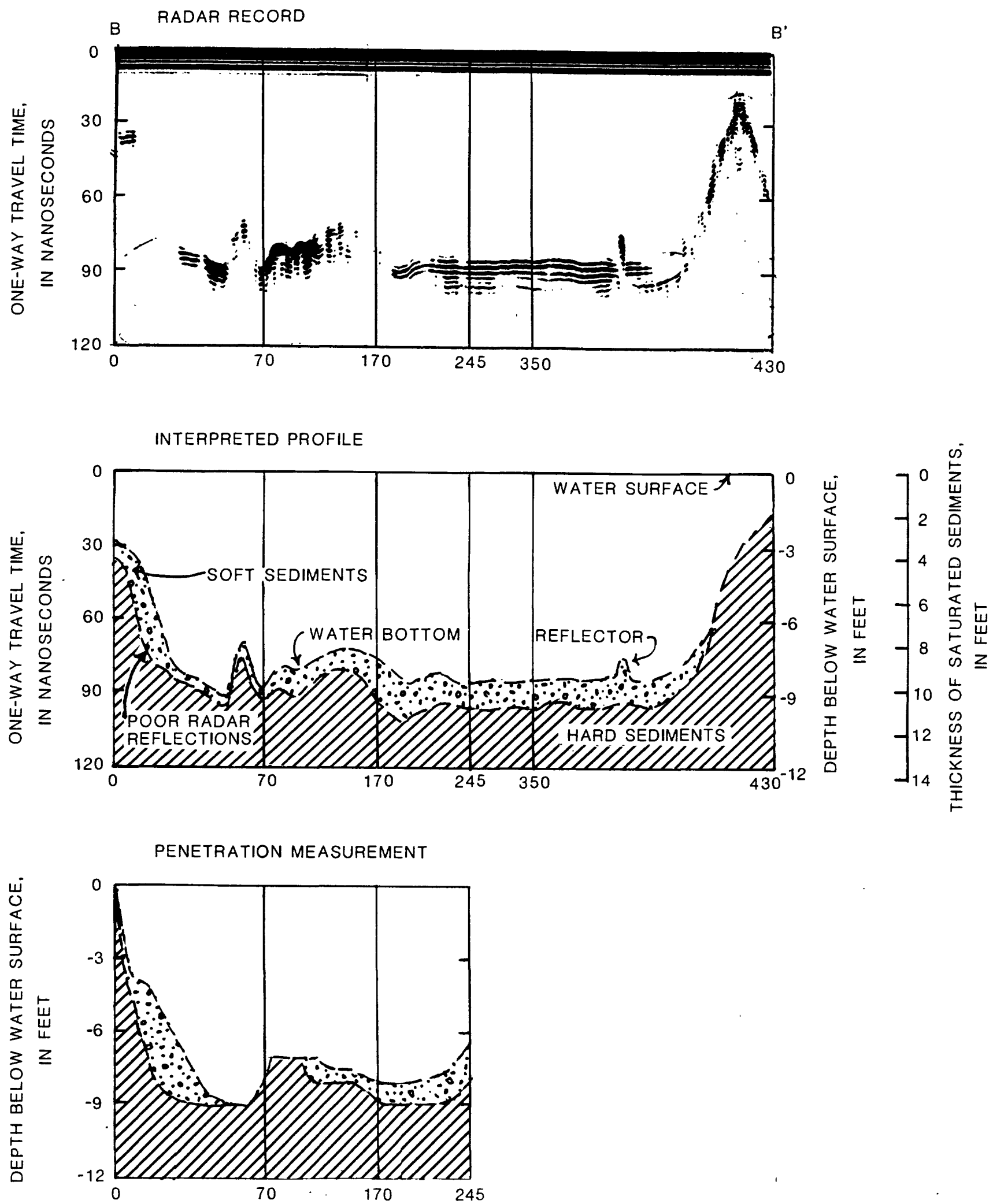

DISTANCE FROM WESTERN SHORE, IN FEET (NONUNIFORM SCALE)

Figure 6.--Field radar record, interpreted profile line, and penetration measurements for profile line B-B' in Reservoir 2, Framingham and Ashland, Massachusetts, 1989. 


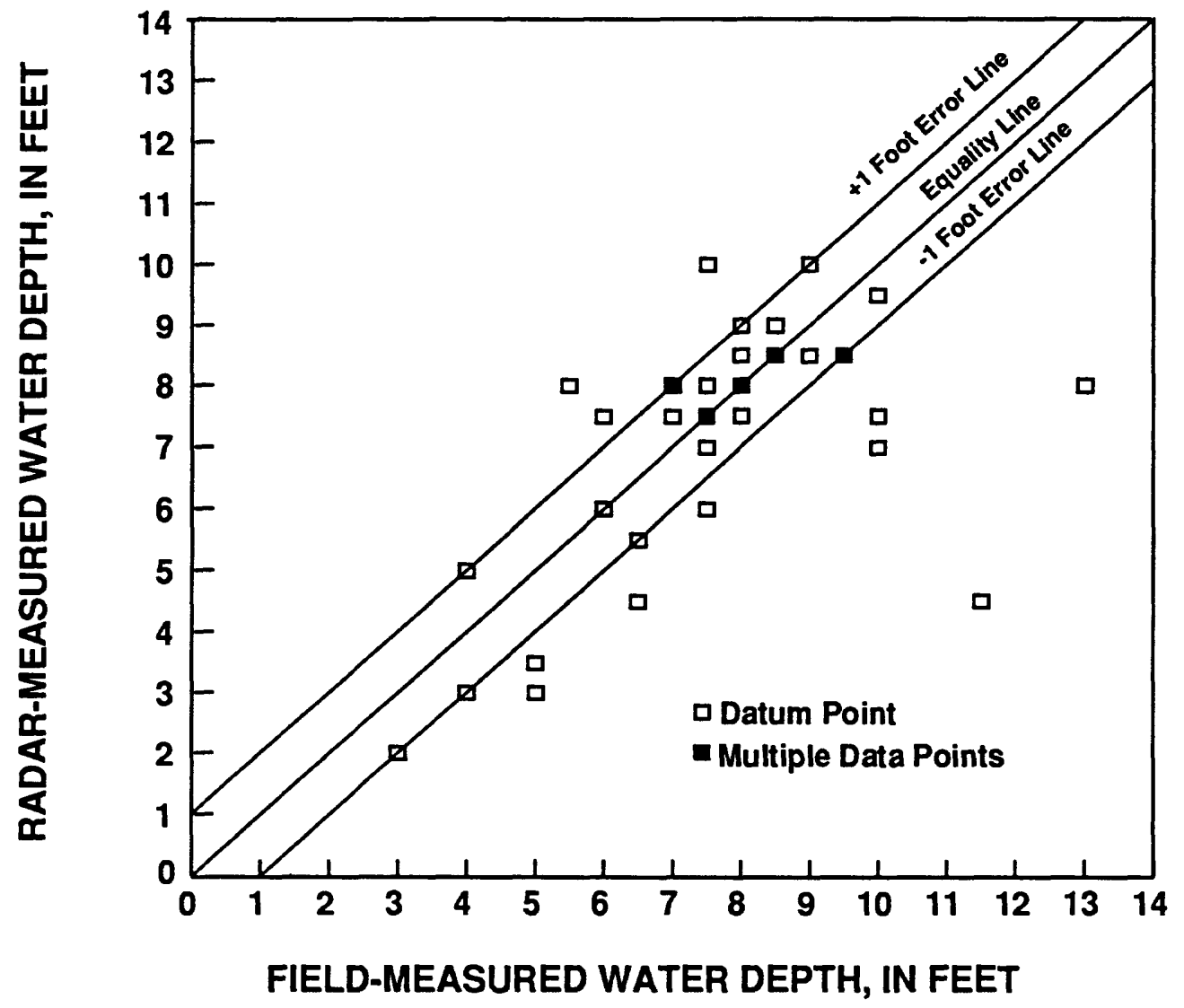

Figure 7.--Comparisons of water depths using ground-penetrating radar and field measurements in Reservoirs 1 and 2, Framingham and Ashland, Massachusetts, 1989. 


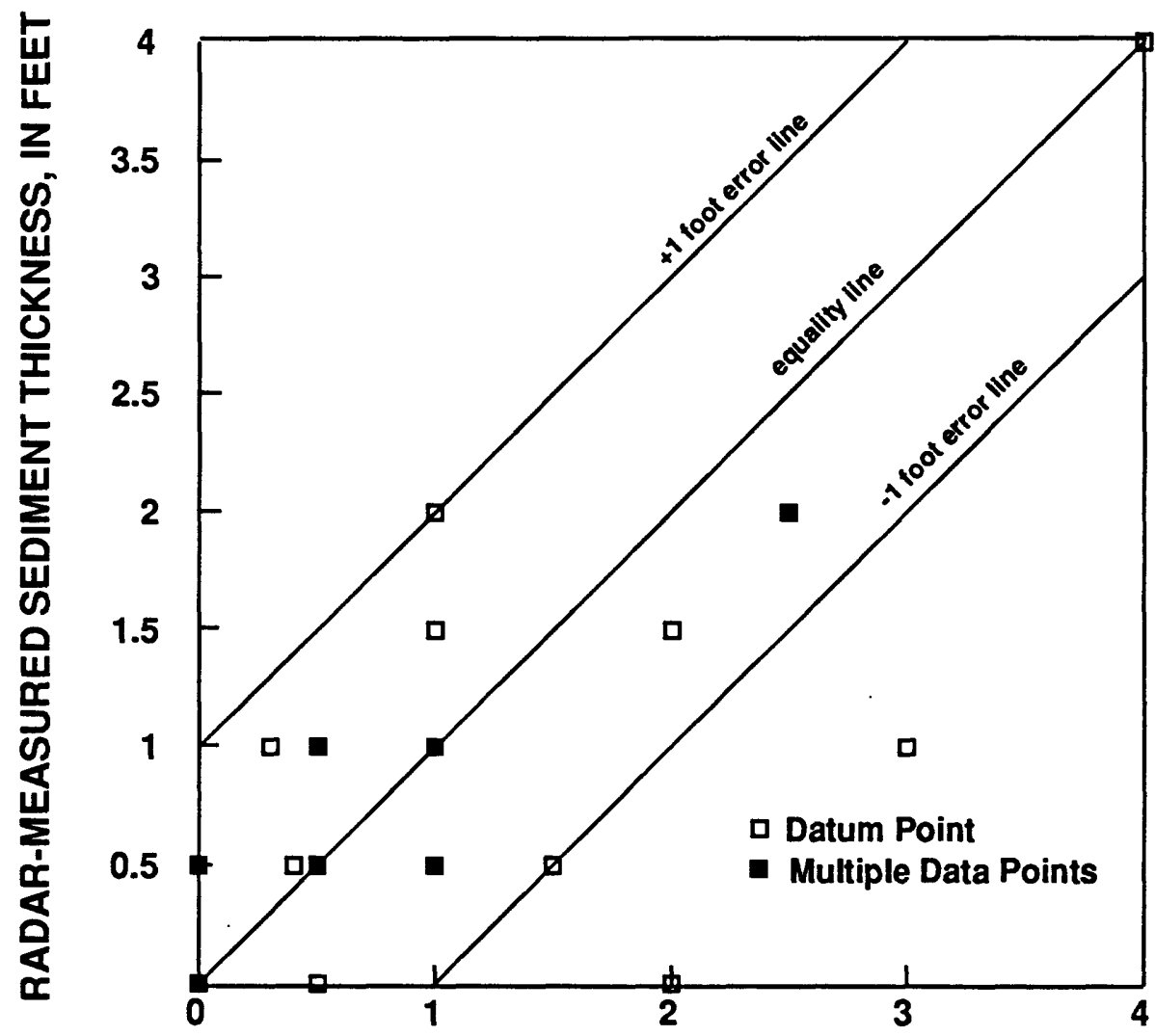

FIELD-MEASURED SEDIMENT THICKNESS, IN FEET

Figure 8.--Comparisons of soft-sediment thickness using ground-penetrating radar and field measurements in Reservoirs 1 and 2, Framingham and Ashland, Massachusetts, 1989. 


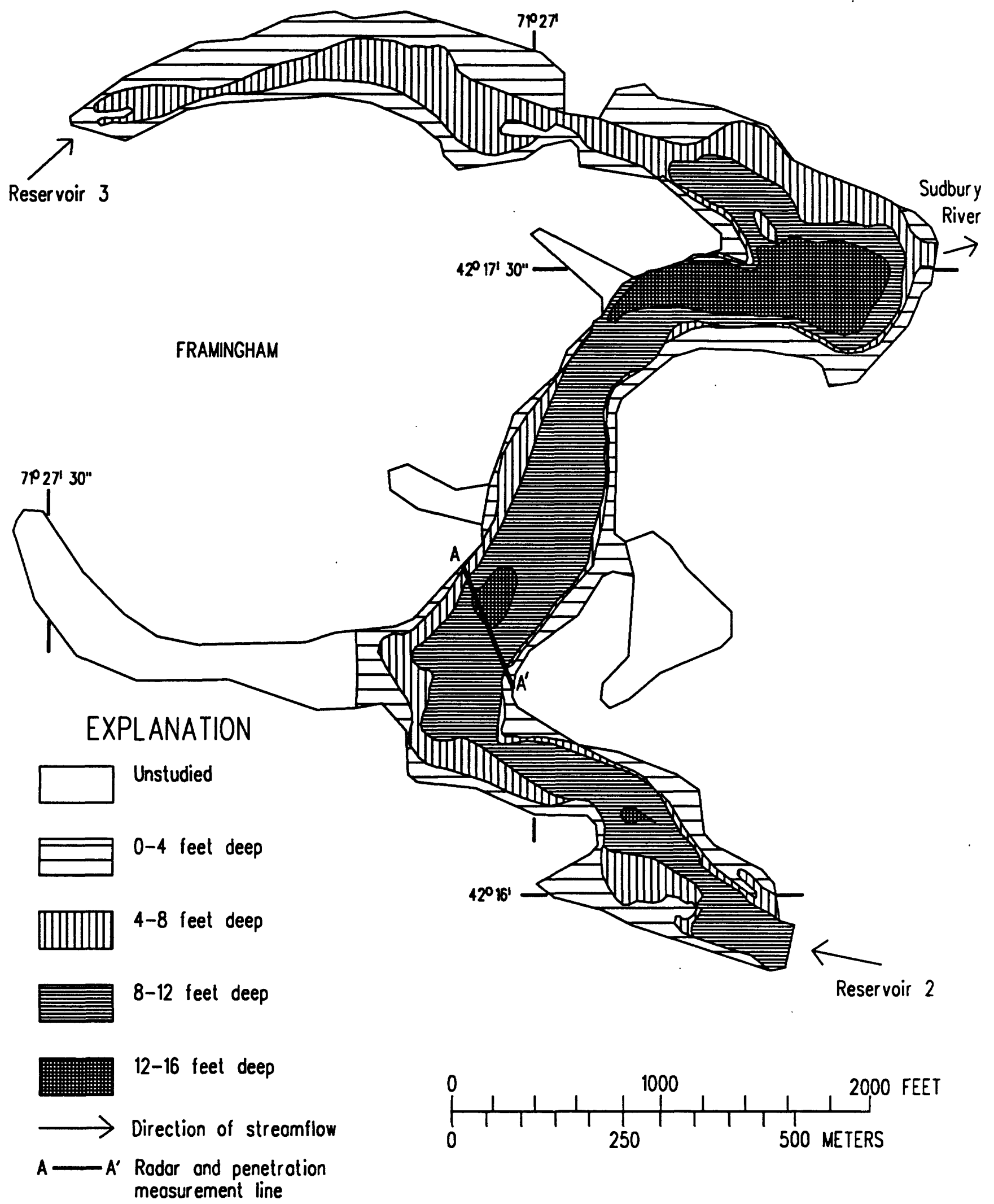

Figure 9.--Woter depth in Reservoir 1, Framinghom, Mossochusetts, 1989 


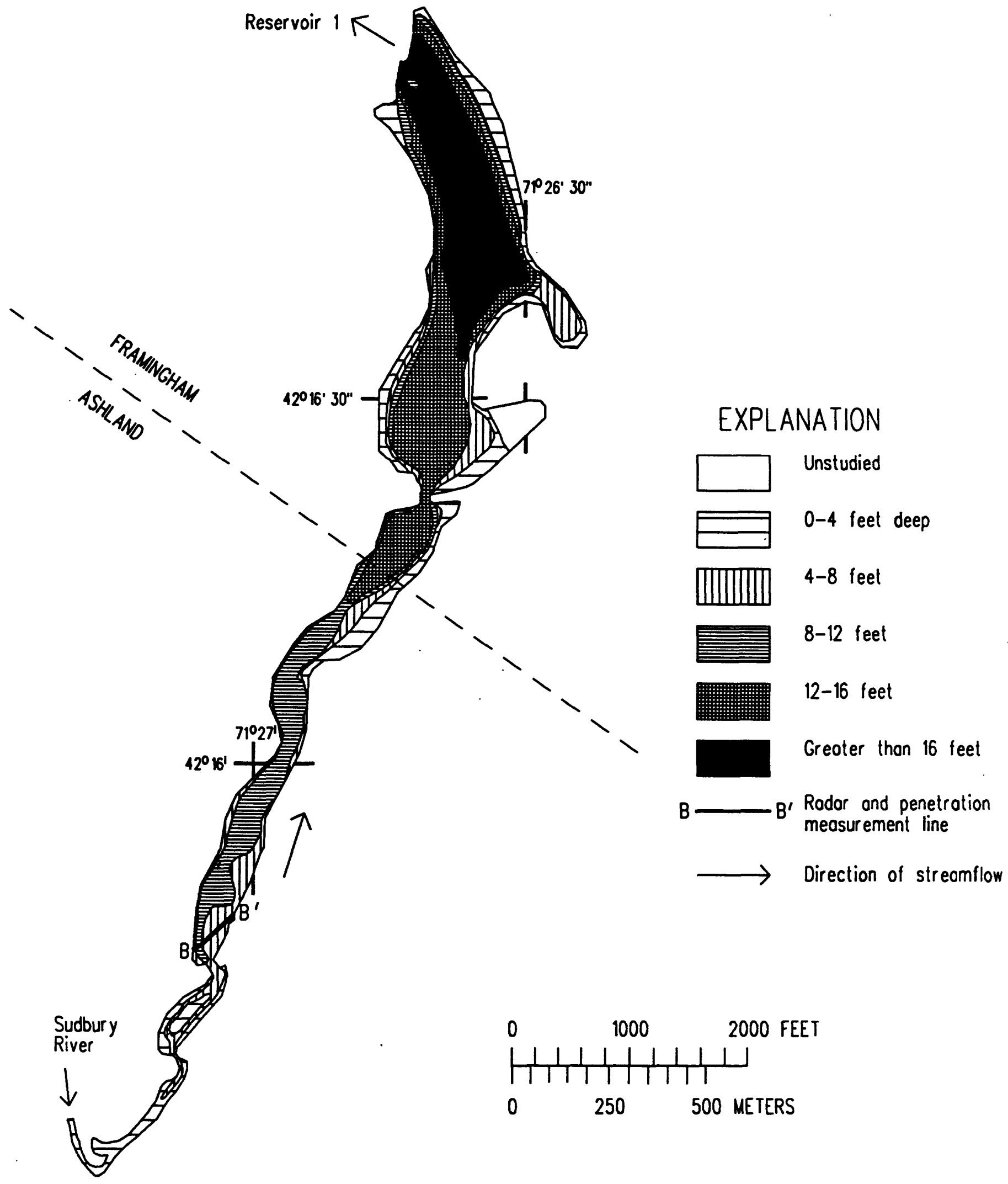

Figure 10.--Woter depth in Reservoir 2, Frominghom ond Ashlond, Mossochusetts, 1989 
The results of the sediment-thickness survey are shown by hand-drawn contour lines in figures 11 and 12. The areas of maximum sediment thickness in Reservoir 1 (fig. 11) are in the northeastern end and in the northwestern arm. Water depth measurements suggest (fig. 9) a pond was in the northeastern arm prior to the construction of the reservoir. In Reservoir 2, thickest sediments were found near the inlet at the southern end of the reservoir near the Sudbury River inlet (fig. 12) where fine materials settled because of slower water velocities. Sediment deposits in this southern part of Reservoir 2 ranged from 2 to $3 \mathrm{ft}$ thick. A small area of thick sediments was observed at the mouth of a cove on the east shore. This deposit is probably the result of local tributary runoff. Relatively thick sediments in the northwest arm of Reservoir 1 (fig. 11) may have been deposited during the construction of Reservoir 3 and the Sudbury Reservoir (fig 1). The thicker sediment in the upstream part of Reservoir 2 probably was deposited after the reservoirs were completed. Radar profiles and measurements of depth and sediment thickness are available for inspection at the USEPA Office in Boston, Massachusetts.

\section{SUMMARY}

Ground-penetrating radar was used for reconnaissance mapping of water depth and sediment thichness in Reservoirs 1 and 2 in Framingham and Ashland, Massachusetts. More than $7 \mathrm{mi}$ of profile lines were obtained during August 28 to September 1, 1989. Maximum water depth was $13 \mathrm{ft}$ in Reservoir 1 and $18.5 \mathrm{ft}$ in Reservoir 2. Sediment accumulations are generally less than $2 \mathrm{ft}$ in both reservoirs. The areas of maximum sediment thickness in Reservoir 1 are in the northeastern end and in the northwestern arm. In Reservoir 2, thickest sediments were found near the inlet at the southern end of the reservoir near the Sudbury River inlet (fig. 12) where fine materials settled because of slower water velocities. Water depths and sediment thicknesses from the soundings and penetration measurements were compared to GPR surveys for 43 locations. Most interpreted radar-measured values were within $1 \mathrm{ft}$ of the measured water depth and sediment thickness.

\section{REFERENCES CITED}

Brackley, R. A, Hansen, B. P., 1985, Hydrology and water resources of tributary basins to the Merrimack River from Salmon Brook to the Concord River, Massachusetts: U.S. Geological Survey Hydrologic Investigation Atlas 662, 2 maps.

Haeni, F. P., McKeegan, D. K, and Capron, D. R., 1987, Ground-penetrating radar study of the thickness and extent of sediments beneath Silver Lake, Berlin and Meriden, Connecticut: U.S. Geological Survey Water-Resources Investigations Report 85-4108, 19 p.

Izbicki, J. A., deLima, V. A, and Hansen, B. P., 1988, Use of photography, seismic reflection, and ground-penetrating radar to determine lithology of streambed and aquifer deposits: 24th Annual Meeting of the Northeastern Section of the Geological Society of America, $p$ 24.

Markt, George, 1988, Subsurface characterization of hazardous waste sites using groundpenetrating radar: Second International Symposium on Geotechnical Applications of Ground-Penetrating Radar, March 6-10, 1988, 41 p.

Olhoeft, G. R., 1984, Applications and limitations of ground-penetrating radar: Society of Exploration Geophysicists, Fifty-fourth Annual International Meeting, Atlanta, Georgia, p 147-148.

U.S. Geological Survey, 1989, Water resources data, Massachusetts and Rhode Island, water year 1987: U.S. Geological Survey Water-Data Report MA-RI-87-1, 243 p. 


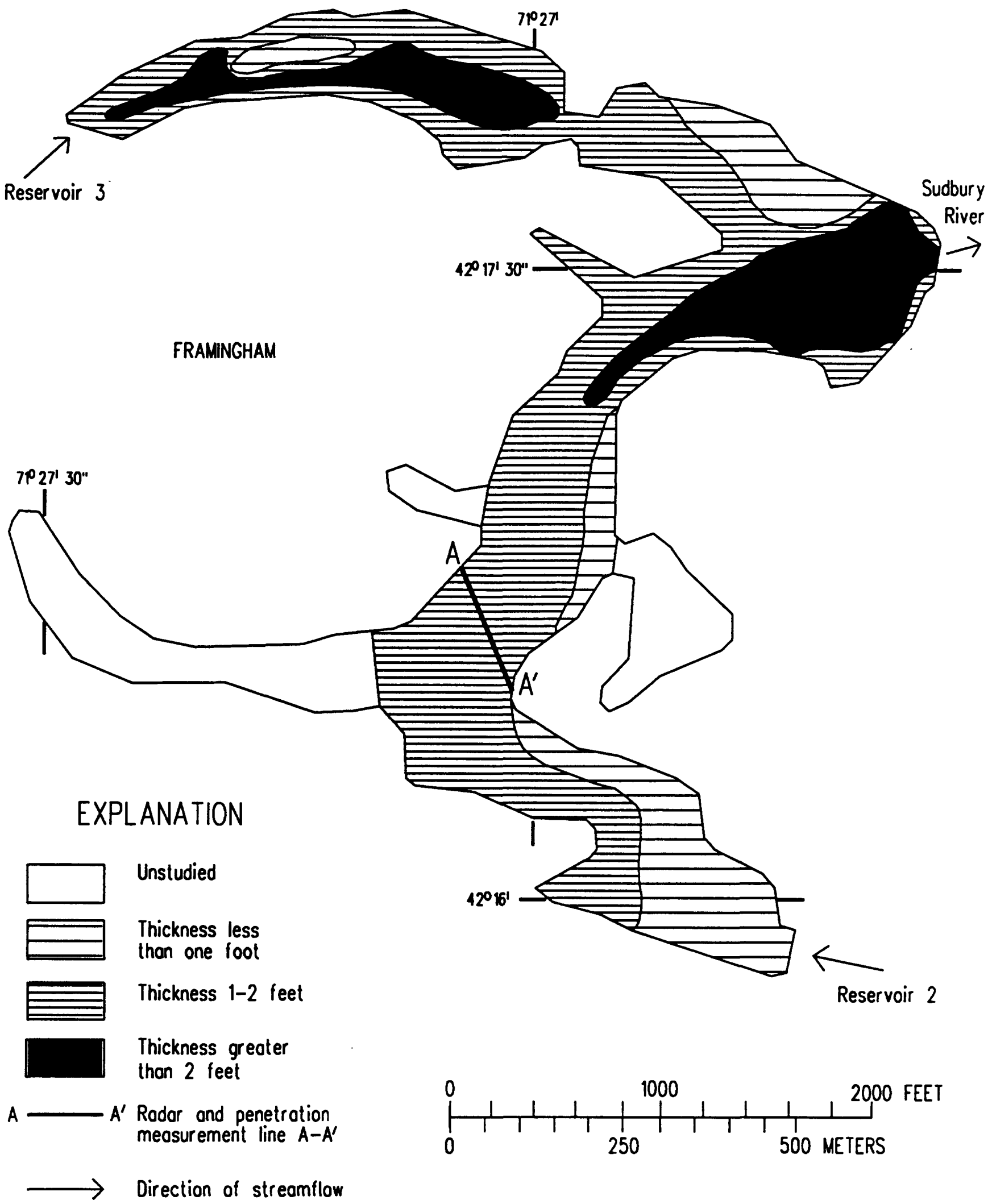

Figure 11.--Sediment distribution in Reservoir 1, Framinghom, Mossachusetts, 1989 


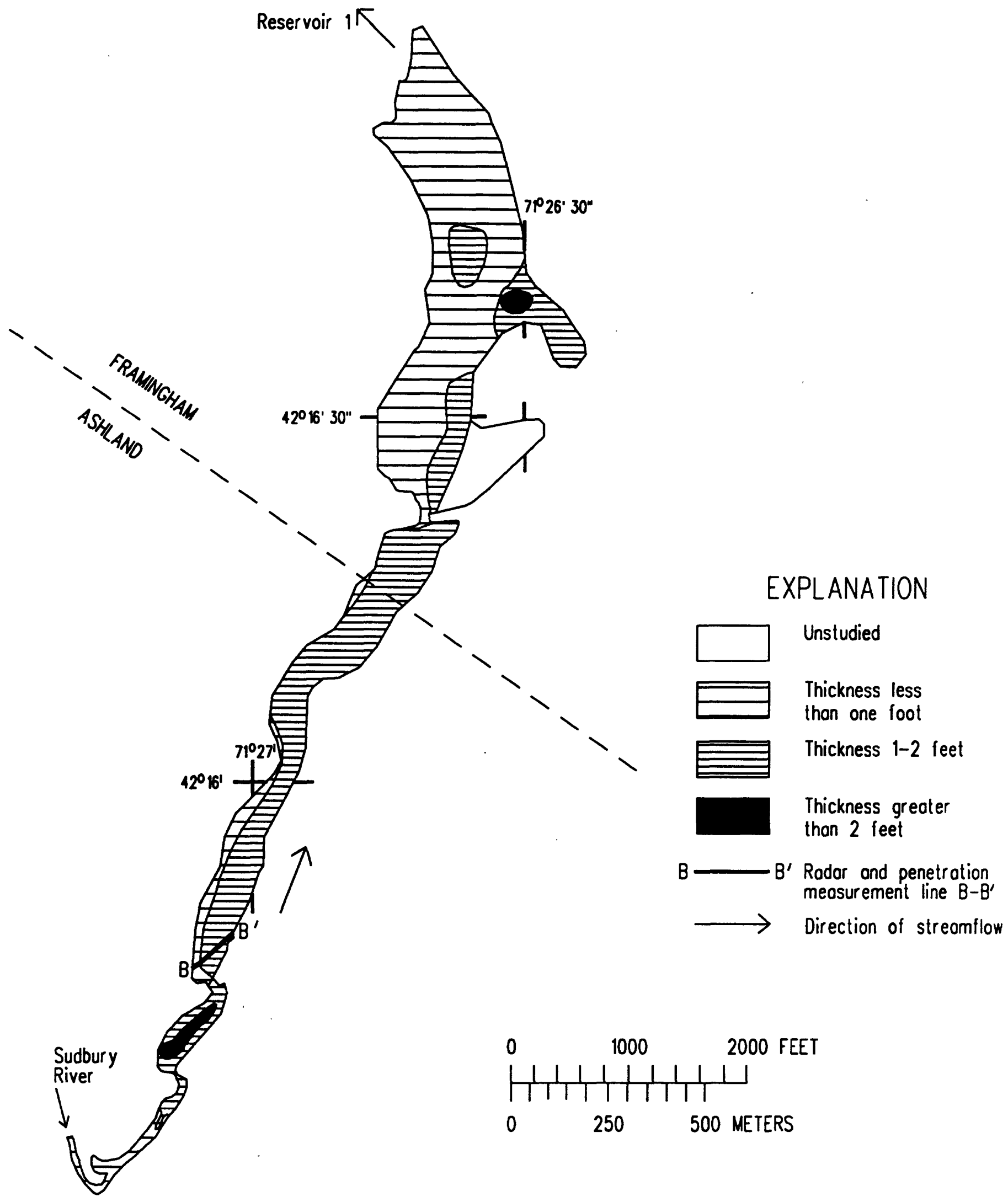

Figure 12.--Sediment distribution in Reservoir 2, Framinghom and Ashland, Massachusetts, 1989 